\section{Epidemiology of leisure-time physical activity: a population-based study in southern Brazil}

\author{
Epidemiologia da atividade física no lazer: \\ um estudo de base populacional no sul do Brasil
}

Juvenal Soares Dias-da-Costa 1

Pedro Curi Hallal 1

Jonathan Charles Kingdon Wells 2

Tiago Daltoé 1

Sandra Costa Fuchs 3

Ana Maria Baptista Menezes 1

Maria Teresa Anselmo Olinto 4

\title{
Introduction
}

1 Programa de Pós-graduação

em Epidemiologia,

Universidade Federal

de Pelotas, Pelotas, Brasil.

2 MRC Childhood Nutrition

Research Centre, Institute

of Child Health, London,

United Kingdom.

3 Departamento de Medicina

Social, Universidade

Federal do Rio Grande do

Sul, Porto Alegre, Brasil.

4 Centro de Ciências da

Saúde, Universidade

do Vale do Rio dos Sinos,

São Leopoldo, Brasil.

Correspondence

P. C. Hallal

Programa de Pós-graduação

em Epidemiologia,

Universidade Federal

de Pelotas. Av. Duque de

Caxias 250, 3o andar,

Pelotas, RS 96030-002, Brasil.

prchallal@terra.com.br

\section{Abstract}

We aimed to measure the prevalence of physical inactivity (PI) during leisure time and to identify variables associated with it in a southern Brazilian adult population. A population-based cross-sectional study was carried out, covering a multiple-stage sample of 1,968 subjects aged 2069 years. Weekly participation in leisure-time physical activity was addressed. For each activity, energy expenditure was calculated using data on duration, metabolic equivalent, and body weight. Energy expenditures of individual activities were summed to give a weekly total. PI was defined as fewer than 1,000 kilocalories per week. The prevalence of PI was $80.7 \%$ (95\%CI: 78.9-82.4). After adjusted analyses, the following variables were positively associated with the outcome: female gender, age, living with a partner, and smoking. Schooling and economic status were inversely associated with PI. Chronically undernourished individuals were significantly more likely to be inactive. We found no differences according to skin color or alcohol consumption. In conclusion, the prevalence of PI in this adult population was higher than in populations from developed countries, but the associated variables were similar.

Exercise; Risk Factors; Adults; Life Style
In recent decades, an economic transition has contributed to changes in the epidemiological profile of disease, with a reduction in infectious diseases and an increase in lifestyle-related illnesses 1 . Sedentary lifestyle is a risk factor for several chronic diseases, such as coronary heart disease 2 , breast cancer 3 , prostate cancer 4 and depression 5 , and for all-cause mortality 6 .

The intensity and frequency of activities can influence the magnitude of their effect on chronic diseases. However, even light and moderate activities are associated, for example, with a lower risk of coronary heart disease in women 7 , and moderate activities reduce all-cause mortality in men ${ }^{6}$. Despite this evidence for the benefits of an active lifestyle for health, high percentages of many populations are not sufficiently active to obtain such health benefits 8,9,10.

The amount of data available in developing countries (or those undergoing nutritional transition) is less abundant. In Brazil, Monteiro et al. 11 evaluated leisure-time physical activity in two Brazilian regions (Southeast and Northeast), and only $3.3 \%$ of the interviewees had performed at least 30 minutes of activity on five or more days of the week. Hallal et al. 12 and Matsudo et al. 13 addressed all physical activity (associated with leisure time, occupation, housework, and transportation), and both found an inactivity prevalence of some $40.0 \%$. Barros \& 
Nahas 14 evaluated leisure-time activity in a sample of industrial workers, and the prevalence of inactivity was $68.1 \%$.

This study aimed to measure the prevalence of leisure-time physical inactivity and associated variables in a southern Brazilian adult population.

\section{Methods}

Pelotas is a city of approximately 320,000 inhabitants in the extreme South of Brazil. A crosssectional study was conducted in the adult population (20-69 years), investigating several health-related variables, including leisure-time physical activity.

The sample size calculation used the following parameters: $95 \%$ confidence interval; $80.0 \%$ power; independent variable prevalence ranging from 5.0 to $50.0 \%$; relative risk of $2.0 ; 70.0 \%$ estimated prevalence of leisure-time inactivity; $10.0 \%$ excess for non-response; and $15.0 \%$ excess for adjusted analyses. Although these calculations predicted a sample of approximately 900 individuals, the final sample included 1,968 subjects, because this study (as mentioned above) was part of a larger health survey in the same population.

The sample was selected in multiple stages. At first, all 281 census tracts in the city were listed, and 40 were systematically selected for the study. Next, 30 households were systematically selected in each chosen census tract. All residents in the selected households aged 2069 years were eligible for the study.

Fieldwork was conducted from December 1999 to March 2000. A standardized pre-tested questionnaire was applied using face-to-face interviews. Interviewers were university students who underwent comprehensive training, including standardization of weight and height measurements. Interviewers were blind to the study objectives and hypotheses.

The physical activity questionnaire addressed several leisure-time activities practiced in each week of the previous month. For each activity, information concerning duration (minutes) and frequency was collected. For each activity, energy expenditure was calculated from the metabolic equivalent 15 , duration of the activity, and body weight. Total weekly leisure-time energy expenditure was obtained by summing the values for the individual activities. Physical inactivity in leisure time was defined as weekly energy expenditure below $1,000 \mathrm{kcal}$, in accordance with moderate physical activity guidelines 16.
The independent variables were: gender, age, skin color (divided into white, black, or mixed-race, as observed by the interviewer), partner status (living with or without a partner), schooling (in complete years), socioeconomic status (divided into five categories according to the classification of the Brazilian National Association of Research Institutes, ANEP, which considers both household assets and paternal education, and where $\mathrm{A}$ is the highest group), body mass index (BMI, categorized as: chronic energy deficiency $<18.5 \mathrm{~kg} / \mathrm{m}^{2}$; underweight $18.5-19.9 \mathrm{~kg} / \mathrm{m}^{2}$; normal $20.0-24.9 \mathrm{~kg} / \mathrm{m}^{2}$; overweight $25.0-29.9 \mathrm{~kg} / \mathrm{m}^{2}$; obesity $\geq 30 \mathrm{~kg} / \mathrm{m}^{2}$ ) 17,18 , smoking (never smoked, former smoker, light/moderate smoker, or heavy smoker), and alcohol consumption (never, $<30 \mathrm{~g} /$ day, or $\geq 30 \mathrm{~g} /$ day). Since subjective classification of skin color could lead to inconsistency, interviewers received standardized training on this issue.

The questionnaire and guidelines were tested in a pilot study in a census tract not included in the final sample. Weight was measured with a portable scale, calibrated weekly (Uniscale, UNICEF, Copenhagen). Height was measured with a locally made anthropometer with a precision of $0.1 \mathrm{~cm}$.

A quality control exercise was conducted in $10.0 \%$ of the sample, randomly selected. Double data entry was used in order to decrease errors. Poisson regression models following a hierarchical approach 19 were used for the adjusted analyses. The hierarchical model was divided into three levels, incorporating the following variables: (1) gender, age, and skin color; (2) schooling, socioeconomic level, and partner status; and (3) BMI, smoking, and alcohol consumption. The association between each variable and the outcome was controlled for the variables in its same level or above in the hierarchical model 19. Poisson rather than logistic regression was selected because in initial analyses the outcome was found to be common, and the odds ratio provided by the logistic model would seriously overestimate the actual prevalence ratios 20 .

The Institutional Review Board/Ethics Committee of the Federal University in Pelotas approved the project. Informed consent was obtained from each participant.

\section{Results}

In the selected households, 2,177 eligible individuals were located, of whom 1,968 (90.4\%) agreed to answer the questionnaire. Seven subjects were unable to provide adequate informa- 
tion on physical activity and were classified as missing values. Therefore, analyses were undertaken using 1,961 subjects.

Table 1 shows a description of the sample. Mean age was 41.6 (SD 13.6) years. Thirty percent of the sample had a monthly family income below US\$ 60. Mean schooling was 7.8 years (SD 4.4 ), and $17.0 \%$ had some university education. Approximately $5.0 \%$ each of the sample belonged to socioeconomic classes A and E (highest and lowest, respectively). Approximately $30.0 \%$ were current smokers, $14.0 \%$ reported high alcohol consumption, $20.0 \%$ were obese, and $3.0 \%$ presented chronic calorie deficiencies.

Table 2 shows detailed data on leisure-time physical activity patterns. Prevalence of physical inactivity was $80.6 \%$ (95\%CI: 78.9-82.4). Distribution was positively skewed. The average was 698 (SD 1792) kcal per week. More than half of the sample (58.6\%) scored zero kcal per week in leisure-time physical activity.

Table 3 shows the crude prevalence of physical inactivity in relation to the independent variables, and also the crude prevalence ratios and respective $95 \%$ confidence intervals. Women, those living with a partner, smokers, and those underweight or with chronic energy deficiency had a significant higher prevalence of inactivity. Also in the crude analysis, age was positively associated with low leisure-time physical activity, while schooling, economic level, and alcohol consumption were inversely related to the outcome. This analysis showed no differences in terms of skin color.

Table 4 presents the adjusted analysis using Poisson regression. The effects of gender, age, skin color, partner status, schooling, socioeconomic level, and smoking remained the same in the adjusted analysis. Alcohol consumption failed to remain significant after controlling for the variables in its level and in higher levels in the hierarchical model. There was a negative relationship between BMI and inactivity. Individuals with low BMI were more likely to be inactive, and those overweight and obese were more active.

All analyses were repeated separately for men and women. Although the prevalence of inactivity was higher in men than women, the variables associated with inactivity were similar for both sexes, and therefore these results are not shown.

\section{Discussion}

This study found a high prevalence of leisuretime inactivity and a number of demographic, socioeconomic, and behavioral factors associ-
Description of the sample in terms of demographic, socioeconomic, anthropometric, and behavioral variables. Pelotas, Rio Grande do Sul, Brazil, 2003.

\begin{tabular}{|c|c|c|}
\hline Variable & Number & $\%$ \\
\hline \multicolumn{3}{|l|}{ Gender } \\
\hline Male & 846 & 43.0 \\
\hline Female & 1,122 & 57.0 \\
\hline \multicolumn{3}{|l|}{ Age (years) } \\
\hline $20-24$ & 261 & 13.3 \\
\hline $25-34$ & 409 & 20.8 \\
\hline $35-44$ & 481 & 24.4 \\
\hline $45-54$ & 409 & 20.8 \\
\hline $55-69$ & 407 & 20.7 \\
\hline \multicolumn{3}{|l|}{ Skin color } \\
\hline White & 1,634 & 83.0 \\
\hline Mixed & 159 & 8.1 \\
\hline Black & 175 & 8.9 \\
\hline \multicolumn{3}{|l|}{ Partner status } \\
\hline Living with a partner & 1,205 & 61.2 \\
\hline Living without a partner & 763 & 38.8 \\
\hline \multicolumn{3}{|l|}{ Schooling (years of formal education) } \\
\hline 0 & 88 & 4.5 \\
\hline $1-4$ & 424 & 21.5 \\
\hline $5-8$ & 631 & 32.0 \\
\hline $9-11$ & 491 & 25.0 \\
\hline$\geq 12$ & 334 & 17.0 \\
\hline \multicolumn{3}{|l|}{ Socioeconomic level* } \\
\hline A & 110 & 5.6 \\
\hline B & 500 & 23.6 \\
\hline C & 726 & 37.1 \\
\hline $\mathrm{D}$ & 529 & 27.1 \\
\hline$E$ & 89 & 4.6 \\
\hline \multicolumn{3}{|l|}{ Smoking status } \\
\hline Never smoked & 945 & 48.0 \\
\hline Former smoker & 423 & 21.5 \\
\hline Light/moderate smoker ( $\leq 20$ cigarettes/day) & 319 & 16.2 \\
\hline Heavy smoker (> 20 cigarettes/day) & 281 & 14.3 \\
\hline \multicolumn{3}{|l|}{ Daily alcohol consumption (ethanol, g/day) } \\
\hline 0 & 411 & 21.0 \\
\hline$\leq 30$ & 1,273 & 65.1 \\
\hline$>30$ & 271 & 13.9 \\
\hline \multicolumn{3}{|l|}{ Body mass index $\left(\mathrm{kg} / \mathrm{m}^{2}\right)$} \\
\hline Chronic energy deficiency $(<18.5)$ & 56 & 2.9 \\
\hline Underweight (18.5-19.9) & 83 & 4.3 \\
\hline Normal (20.0-24.9) & 768 & 39.7 \\
\hline Overweight (25.0-29.9) & 653 & 33.7 \\
\hline Obesity ( $\geq 30.0$ ) & 376 & 19.4 \\
\hline
\end{tabular}

* Classification of the Brazilian National Institute of Research, where $A$ is the highest group. 
Table 2

Description of leisure-time physical activity (PA) patterns. Pelotas, Rio Grande do Sul, Brazil, 2003.

\begin{tabular}{lc}
\hline Parameter & Value \\
\hline Weekly energy expenditure in leisure time PA (kcal/week) & \\
$0-500$ & $71.2 \%$ \\
$501-1,000$ & $9.4 \%$ \\
$1,000-1,999$ & $9.9 \%$ \\
$\geq 2,000$ & $9.4 \%$ \\
Average (SD) weekly energy expenditure in leisure time PA & $698.2 \mathrm{kcal} /$ week \\
& $(1,792.8)$ \\
Percentiles of weekly energy expenditure in leisure time PA & \\
5th & $0.0 \mathrm{kcal} / \mathrm{week}$ \\
25th & $0.0 \mathrm{kcal} / \mathrm{week}$ \\
50th & $0.0 \mathrm{kcal} /$ week \\
75th & $665.5 \mathrm{kcal} / \mathrm{week}$ \\
95 th & $3,395.8 \mathrm{kcal} / \mathrm{week}$ \\
Skewness & 5.8 \\
Kurtosis & 49.2 \\
\hline
\end{tabular}

ated with it. Such information is important for campaigns to promote physical activity.

The prevalence of individuals classified as insufficiently active to obtain health benefits $(80.6 \%)$ was higher than observed in Australia $(67.7 \%)$ 8, the United States $(68.0 \%)$, and industrial workers in the Brazilian State of Santa Catarina $(68.1 \%) 14$. This difference probably stems in part from between-population differences in the time available for leisure-time activity. Our study may differ from that in Santa Catarina 14 because the latter only investigated workers, whereas our sample was representative of the whole population and included elderly people and those unable to work. These categories may be less able to undertake leisuretime activities and hence increase the prevalence of inactivity in our sample.

We observed marked differences in socioeconomic status. Our study showed a lack of leisure-time physical activity in the lowest socioeconomic groups, similar to several studies in developed countries 10,21,22. Our finding is consistent with the hypothesis that higher-income individuals are more likely (whether due to greater motivation or access to resources) to follow preventive programs and health-promoting behavior. Participation in leisure-time activities is reduced among lower-income individuals. On the other hand, their participation in vigorous work-related activities may be high- er than for higher-income individuals, as suggested recently 12 .

In our study men were more active than women during their leisure time. Similar results have been widely reported $8,10,14,23,24,25$. However, when total physical activity was analyzed, no gender differences were found 12,13 .

The positive association between activity level and age is consistent with the literature $8,21,26$, showing a gradual decline in physical activity with increasing age. Retirement has been proposed as a possible explanation 27 .

The relationship between physical activity and partner status has rarely been explored in the literature. An Australian study 8 found that parents with dependent children had lower activity levels than non-parents, single adults, or parents with no dependent children. Both studies indicate that household composition may influence physical activity, but this issue requires further investigation.

Various studies have linked low physical activity to obesity 28,29 . Obesity develops when energy expenditure is lower than energy intake, and reduced physical activity is assumed to be an important etiological factor. However, crosssectional studies have not always found such an association 10,12 . In the present study, overweight individuals had a significantly lower prevalence of low leisure-time activity than normal-weight individuals, and the same trend was observed in the obese, although the effect did not reach significance. Exercise is recommended for management of excess weight, and our findings may reflect the tendency of such individuals to follow this advice.

However, at the other end of the weight spectrum, underweight or chronically energydeficient individuals had a higher prevalence of low activity (the effect was statistically significant in energy-deficient individuals). This could imply that poor nutritional status in this population is due to inadequate energy intake rather than high-energy expenditure. For example, low energy intake is often associated with low physical activity 30 . Another possible explanation is that undernourished individuals have high physical activity levels at work (for example, as reported in malnourished Bangladeshi mothers) 31 . Thus their inactivity in leisure time may be counterbalanced by activities elsewhere. Alternatively, the lower activity levels of those with low BMI may be due to poorer health, as reported in Ethiopia 32 . These explanations would have differing implications for public health campaigns. The prevalence of inactivity in marginally nourished populations therefore merits further research. 
Prevalence of physical inactivity (PI) in leisure time and crude prevalence ratios (PR) for each independent variable in relation to the outcome. Pelotas, Rio Grande do Sul, Brazil, 2003.

\begin{tabular}{|c|c|c|c|}
\hline Variable & $\% \mathrm{PI}$ & PR $(95 \% \mathrm{Cl})$ & $p$-value \\
\hline Gender & & & $<0.001^{*}$ \\
\hline Male & 69.1 & 1.00 & \\
\hline Female & 89.4 & $1.29(1.23-1.36)$ & \\
\hline Age (years) & & & $<0.001 * *$ \\
\hline $20-24$ & 64.1 & 1.00 & \\
\hline $25-34$ & 76.1 & $1.19(1.07-1.32)$ & \\
\hline $35-44$ & 85.2 & $1.33(1.20-1.47)$ & \\
\hline $45-54$ & 82.9 & $1.29(1.17-1.43)$ & \\
\hline $55-69$ & 88.2 & $1.38(1.25-1.52)$ & \\
\hline Skin color & & & $0.430^{*}$ \\
\hline White & 80.3 & 1.00 & \\
\hline Mixed & 81.1 & $1.01(0.93-1.09)$ & \\
\hline Black & 84.0 & $1.05(0.98-1.12)$ & \\
\hline Partner status & & & $0.020^{*}$ \\
\hline Living with a partner & 82.4 & $1.06(1.01-1.11)$ & \\
\hline Living without a partner & 78.0 & 1.00 & \\
\hline Schooling (years of formal education) & & & $<0.001 * *$ \\
\hline 0 & 93.2 & $1.38(1.26-1.52)$ & \\
\hline $1-4$ & 87.9 & $1.30(1.20-1.42)$ & \\
\hline $5-8$ & 82.6 & $1.22(1.13-1.33)$ & \\
\hline $9-11$ & 78.6 & $1.16(1.07-1.27)$ & \\
\hline$\geq 12$ & 67.5 & 1.00 & \\
\hline \multicolumn{4}{|l|}{ Socioeconomic level ${ }^{\star \star \star}$} \\
\hline A & 64.6 & 1.00 & $<0.001 * \star$ \\
\hline B & 78.5 & $1.22(1.05-1.41)$ & \\
\hline C & 79.4 & $1.23(1.07-1.42)$ & \\
\hline $\mathrm{D}$ & 85.8 & $1.33(1.15-1.53)$ & \\
\hline$E$ & 92.1 & $1.43(1.23-1.66)$ & \\
\hline Smoking status & & & $0.010^{*}$ \\
\hline Never smoked & 78.9 & 1.00 & \\
\hline Former smoker & 80.2 & $1.02(0.96-1.08)$ & \\
\hline Light/moderate smoker ( $\leq 20$ cigarettes/day) & 82.7 & $1.05(0.99-1.11)$ & \\
\hline Heavy smoker (> 20 cigarettes/day) & 85.0 & $1.08(1.02-1.14)$ & \\
\hline Daily alcohol consumption (ethanol, g/day) & & & $<0.001 * *$ \\
\hline 0 & 86.6 & 1.00 & \\
\hline$\leq 30$ & 79.8 & $0.92(0.88-0.97)$ & \\
\hline$>30$ & 75.1 & $0.87(0.80-0.94)$ & \\
\hline Body mass index $\left(\mathrm{kg} / \mathrm{m}^{2}\right)$ & & & $0.880 * \star$ \\
\hline Chronic energy deficiency $(<18.5)$ & 92.9 & $1.17(1.08-1.27)$ & $0.001 *$ \\
\hline Underweight (18.5-19.9) & 84.3 & $1.07(0.96-1.18)$ & \\
\hline Normal (20.0-24.9) & 79.2 & 1.00 & \\
\hline Overweight (25.0-29.9) & 77.9 & $0.98(0.93-1.04)$ & \\
\hline Obesity ( $\geq 30.0$ ) & 84.6 & $1.07(1.01-1.13)$ & \\
\hline
\end{tabular}

* Wald test for heterogeneity of proportions;

$\star *$ Wald test for trend;

*** Classification of the Brazilian National Institute of Research, where A is the highest group. 
Variables associated with physical inactivity (PI) in leisure time, with adjusted prevalence ratios (PR) and confidence intervals (Cl). Pelotas, Rio Grande do Sul, Brazil, 2003.

\begin{tabular}{|c|c|c|c|}
\hline Level* & Variable & PR $(95 \% \mathrm{Cl})$ & p-value \\
\hline \multirow[t]{3}{*}{1} & Gender & & $<0.001^{\star *}$ \\
\hline & Male & 1.00 & \\
\hline & Female & $1.27(1.21-1.34)$ & \\
\hline \multirow[t]{6}{*}{1} & Age (years) & & $<0.001^{\star \star *}$ \\
\hline & $20-24$ & 1.00 & \\
\hline & $25-34$ & $1.14(1.03-1.26)$ & \\
\hline & $35-44$ & $1.27(1.16-1.40)$ & \\
\hline & $45-54$ & $1.25(1.13-1.37)$ & \\
\hline & $55-69$ & $1.32(1.20-1.45)$ & \\
\hline \multirow[t]{4}{*}{1} & Skin color & & $0.470^{\star \star}$ \\
\hline & White & 1.00 & \\
\hline & Mixed & $1.04(0.96-1.12)$ & \\
\hline & Black & $1.03(0.96-1.10)$ & \\
\hline \multirow[t]{3}{*}{2} & Partner status & & \\
\hline & Living with a partner & $1.06(1.02-1.11)$ & $0.007 * \star$ \\
\hline & Living without a partner & 1.00 & \\
\hline \multirow[t]{6}{*}{2} & Schooling (years of formal education) & & $0.005^{\star \star \star}$ \\
\hline & 0 & $1.14(1.03-1.27)$ & \\
\hline & $1-4$ & $1.16(1.06-1.27)$ & \\
\hline & $5-8$ & $1.15(1.05-1.25)$ & \\
\hline & $9-11$ & $1.13(1.03-1.23)$ & \\
\hline & $\geq 12$ & 1.00 & \\
\hline \multirow[t]{6}{*}{2} & Socioeconomic level $\left.\right|^{\star \star \star \star}$ & & $0.001 * * *$ \\
\hline & A & 1.00 & \\
\hline & B & $1.16(1.01-1.33)$ & \\
\hline & C & $1.15(1.00-1.32)$ & \\
\hline & $\mathrm{D}$ & $1.20(1.04-1.39)$ & \\
\hline & $E$ & $1.32(1.13-1.54)$ & \\
\hline \multirow[t]{5}{*}{3} & Smoking status & & $0.010^{* *}$ \\
\hline & Never smoked & 1.00 & \\
\hline & Former smoker & $1.03(0.98-1.09)$ & \\
\hline & Light/moderate smoker ( $\leq 20$ cigarettes/day) & $1.04(0.98-1.10)$ & \\
\hline & Heavy smoker (> 20 cigarettes/day) & $1.11(1.05-1.18)$ & \\
\hline \multirow[t]{4}{*}{3} & Daily alcohol consumption (ethanol, g/day) & & $0.570^{\star \star \star}$ \\
\hline & 0 & 1.00 & \\
\hline & $\leq 30$ & $1.01(0.93-1.10)$ & \\
\hline & $>30$ & $0.98(0.90-1.08)$ & \\
\hline \multirow[t]{6}{*}{3} & Body mass index $(\mathrm{kg} / \mathrm{m} 2)$ & & $0.040 * \star \star *$ \\
\hline & Chronic energy deficiency $(<18.5)$ & $1.15(1.06-1.25)$ & $<0.001 * \star$ \\
\hline & Underweight (18.5-19.9) & $1.07(0.97-1.17)$ & \\
\hline & Normal (20.0-24.9) & 1.00 & \\
\hline & Overweight (25.0-29.9) & $0.94(0.90-0.99)$ & \\
\hline & Obesity ( $\geq 30.0)$ & $0.96(0.91-1.02)$ & \\
\hline
\end{tabular}

* Level of the variable in the hierarchical model;

** Wald test for heterogeneity of proportions;

$\star * \star$ Wald test for trend;

$\star \star \star \star$ Classification of the Brazilian National Institute of Research, where A is the highest group.

Note: The effect of each variable on $\mathrm{PI}$ is adjusted for variables in its same level or above

in the hierarchical model with $p$-value $<0.20$ 
The main limitation of this study is that it focused only on leisure-time activity and did not include activity during transportation, work, or housework. Individuals who are inactive during leisure time may be more active in other contexts. For example, a Russian study 33 concluded that lack of information on transportation physical activities led to a $67.0 \%$ overestimate in the proportion of low physical activity. Furthermore, the proportion of time available for leisure may differ between subsections of the population, and it is possible that the lower activity of women compared to men may reflect differential contributions from housework. However, our results can be compared to those of other studies in Brazil 11,14 and elsewhere 8,9 focusing on the same variable. A new standardized questionnaire has recently been developed to assess total daily activity level more comprehensively 34 . One should note that our data were gathered between 1999 and 2000, and due to the fact that Brazil is undergoing a rapid epidemiological transition,

\section{Resumo}

O objetivo deste estudo foi avaliar a prevalência de inatividade física (IF) no lazer e fatores associados, em uma população adulta (20-69 anos), residente no sul do Brasil. Um estudo transversal de base populacional foi conduzido, com amostragem em múltiplos estágios. A prática semanal de atividade física foi avaliada. Para cada atividade, o gasto energético foi calculado usando dados de duração, equivalentes metabólicos e peso corporal. Os gastos energéticos das atividades foram somados para calcular-se um gasto semanal total. IF foi definida como gasto semanal inferior a 1.000kcal/semana. A prevalência de IF foi de $80,7 \%$ (IC95\%: 78,9-82,4). Após análise ajustada, as seguintes variáveis se associaram positivamente com IF: sexo feminino, idade, viver com companheiro e tabagismo. Escolaridade e nível econômico se associaram inversamente com IF. Indivíduos com índice de massa corporal baixo $\left(<18,5 \mathrm{~kg} / \mathrm{m}^{2}\right)$ apresentaram prevalência significativamente maior de IF. Não foram encontradas diferenças estatisticamente significativas de acordo com a cor da pele e consumo de álcool. A prevalência de IF nesta população adulta foi maior do que em populações de países desenvolvidos, mas as variáveis associadas foram similares.

Exercício; Fatores de Risco; Adultos; Estilo de Vida physical activity patterns found in our study may be changing rapidly. Therefore, similar studies are required to evaluate temporal trends.

Nevertheless, as developing countries undergo nutritional transition and the associated industrialization, activities during leisure time will make an increasingly important contribution to total activity. The high prevalence of inactivity we observed in leisure time among this largely urban population is therefore a concern.

In conclusion, levels of leisure-time physical activity in Pelotas, Brazil, were low, and the prevalence of inactivity was associated with various socio-demographic variables, largely consistent with the literature. Contrary to most other reports, inactivity was not more common in the obese than in the undernourished. Our study focused on individual determinants of inactivity, but we were unable to take differential access to recreational facilities into account. These issues need to be addressed simultaneously in health promotion programs.

\section{Contributors}

J. S. Dias-da-Costa coordinated the drafting of the research instrument and supervised the field work. P. C. Hallal headed the data analysis process and con trolled the data quality. J. C. K. Wells led the drafting of the article. T. Daltoé supervised the field work. S. C. Fuchs oriented the overall research process and led the elaboration of the study hypotheses and objectives. A. M. B. Menezes coordinated the field work organization. M. T. A. Olinto supervised the field work and elaborated the research instrument.

\section{References}

1. Murray CJL, Lopez AD. Mortality by cause for eight regions of the world: global burden of disease study. Lancet 1998; 349:1269-76.

2. Berlin JA, Colditz GA. A meta-analysis of physical activity in the prevention of coronary heart disease. Am J Epidemiol 1990; 132:612-28.

3. Thune I, Brenn T, Lund E, Gaard M. Physical activity and the risk of breast cancer. N Engl J Med 1997; 336:1269-75.

4. Lee IM, Paffembarger RS, Hsiech C. Physical activity and risk of prostatic cancer among college alumni. Am J Epidemiol 1992; 135:169-79. 
5. Camacho TC, Roberts RE, Lazarus NB, Kaplan GA, Cohen RD. Physical activity and depression: evidence from the Alameda County Study. Am J Epidemiol 1991; 134:220-34.

6. Kujala UM, Kaprio J, Sarna S, Koskenvuo M. Relationship of leisure-time physical activity and mortality: the Finnish twin cohort. JAMA 1996; 144:793-7.

7. Lee IM, Rexrode KM, Cook NR, Manson JE, Buring JE. Physical activity and coronary heart disease in women: is "no pain, no gain" passe? JAMA 2001; 285:1447-54.

8. Burton NW, Turrell G. Occupation, hours worked and leisure-time physical activity. Prev Med 2000; 31:673-81.

9. Martin SB, Morrow JR, Jackson AW, Dunn AL. Variables related to meeting the CDC/ACSM physical activity guidelines. Med Sci Sports Exerc 2000; 32:2087-92.

10. Pomerleau J, McKee M, Robertson A, Vaasc S, Kadziauskiene K, Abaravicius A, et al. Physical inactivity in the Baltic Countries. Prev Med 2000; 31:665-72.

11. Monteiro CA, Conde WL, Matsudo SM, Matsudo VR, Bonseñor IM, Lotufo PA. A descriptive epidemiology of leisure-time physical activity in Brazil, 1996-1997. Rev Panam Salud Publica 2003; 14:246-54

12. Hallal PC, Victora CG, Wells JCK, Lima RC. Physical inactivity: prevalence and associated variables in Brazilian adults. Med Sci Sports Exerc 2003; 38:1894-900.

13. Matsudo SM, Matsudo VR, Araújo T, Andrade D, Oliveira L, Braggion G. Nível de atividade física da população do estado de São Paulo: análise de acordo com o gênero, idade, nível sócio-econômico, distribuição geográfica e de conhecimento. Rev Bras Ciên Mov 2002; 10:41-50.

14. Barros MV, Nahas MV. Comportamentos de risco, auto-avaliação do nível de saúde e percepção de estresse entre trabalhadores da indústria. Rev Saúde Pública 2001; 35:554-63.

15. Ainsworth BE, Haskell WL, Whitt MC, Irwin ML, Swartz AM, Strath SJ, et al. Compendium of physical activities: an update of activity codes and MET intensities. Med Sci Sports Exerc 2000; 32: S498-S516.

16. U.S. Department of Health and Human Services. Physical activity and health: a report from the surgeon general. Atlanta: National Center for Chronic Disease Prevention and Health Promotion; 1996.

17. Garrow GS, Webster G. Quetelet's index (W/H2) as a measure of fatness. Int J Obes 1985; 9:147-53.

18. James WPT, Ferro-Luzzi A, Waterlow JC. Definition of chronic energy deficiency in adults. Eur J Clin Nutr 1994; 42:969-81.

19. Victora CG, Huttly SR, Fuchs SC, Olinto MTA. The role of conceptual frameworks in epidemiological analysis: a hierarchical approach. Int J Epidemiol 1997; 26:224-7.

20. Barros AJ, Hirakata VN. Alternatives for logistic regression in cross-sectional studies: an empirical comparison of models that directly estimate the prevalence ratio. BMC Med Res Methodol 2003; 3:21.
21. Ransdell LB, Wells CL. Physical activity in urban white, African-American, and Mexican-American women. Med Sci Sports Exerc 1998; 27:1608-15.

22. Ford ES, Merrit RK, Heath GW, Powell KE, Washburn RA, Kriska A, et al. Physical activity behaviors in lower and higher socioeconomic status populations. Am J Epidemiol 1991; 133:1246-56.

23. Cauley JA, Donfield SM, LaPorte RE, Warhaftig NE. Physical activity by socioeconomic status in two population based cohorts. Med Sci Sports Exerc 1991; 23:343-52.

24. Van-Heuvelen MJ, Kempen GI, Ormel J, Rispens P. Physical fitness related to age and physical activity in older persons. Med Sci Sports Exerc 1998; 30:434-41.

25. Anderssen N, Jacobs DR, Sidney S, Bild DE, Sternfeld B, Slattery ML, et al. Change and secular trends in physical activity patterns in young adults: a seven-year longitudinal follow-up in the coronary artery risk development in young adults study (CARDIA). Am J Epidemiol 1996; 143:351-62.

26. McMurray RG, Ainsworth BE, Harrell JS, Griggs TR, Williams OD. Is physical activity or aerobic power more influential on reducing cardiovascular disease risk factors? Med Sci Sports Exerc 1998; 30:1521-9.

27. Evenson KR, Rosamond WD, Cai J, Diez-Roux AV, Brancati FL. Influence of retirement on leisuretime physical activity: the atherosclerosis risk in communities study. Am J Epidemiol 2002; 15:692-9.

28. Abdul-Rahim HF, Holmboe-Ottesen G, Stene LC, Husseini A, Giacaman R, Jervell J, et al. Obesity in a rural and an urban Palestinian West Bank population. Int J Obes 2003; 27:140-6.

29. Hu G, Pekkarinen H, Hanninen O, Tian H, Jin R. Comparison of dietary and non-dietary risk factors in overweight and normal-weight Chinese adults. Br J Nutr 2002; 88:91-7.

30. Shetty PS. Adaptation to low energy intakes: the responses and limits to low intakes in infants, children and adults. Eur J Clin Nutr 1999; 53:S14-33.

31. Vinoy S, Rosetta L, Mascie-Taylor CG. Repeated measurements of energy intake, energy expenditure and energy balance in lactating Bangladeshimothers. Eur J Clin Nutr 2000; 54:579-85.

32. Alemu T, Lindtjorn B. Physical activity, illness and nutritional status among adults in a rural Ethiopian community. Int J Epidemiol 1995; 24:977-83.

33. Tudor-Locke C, Neff LJ, Ainsworth BE, Addy CL, Popkin BM. Omission of active commuting to school and the prevalence of children's health-related physical activity levels: the Russian Longitudinal Monitoring Study. Child Care Health Dev 2002; 28:507-12.

34. Craig CL, Marshall Al, Sjostrom M, Bauman AE, Booth ML, Ainsworth BE, et al. International Physical Activity Questionnaire: 12-Country Reliability and Validity. Med Sci Sports Exerc 2003; 35: 1381-95.

Submitted on 13/Jan/2004

Final version resubmitted on 21/May/2004

Approved on 22/Jun/2004 